\title{
Precursors of volatile organic compounds emitted during phosphorite processing
}

\author{
Agata Śliwak $^{1}$, Stanisław Gryglewicz ${ }^{1}$, Józef Hoffmann ${ }^{2}$ and Grażyna Gryglewicz ${ }^{*}$ \\ ${ }^{1}$ Wrocław University of Technology, Faculty of Chemistry, Department of Polymer and Carbonaceous Materials, ul. Gdańska \\ 7/9, 50-344 Wroctaw, Poland \\ ${ }^{2}$ Wroctaw University of Technology, Faculty of Chemistry, Institute of Inorganic Technology and Mineral Fertilizers, ul. Smolu- \\ chowskiego 25, 50-370 Wroctaw, Poland \\ *Corresponding author: e-mail: grazyna.gryglewicz@pwrwroc.pl
}

\begin{abstract}
The composition of solvent-soluble organic matter of phosphorite, which is a precursor of volatile organic compounds emitted by the fertilizer industry, was studied. A benzene-methanol mixture and chloroform were used for the extraction of free and bound bitumen from phosphorites, respectively. The separated bitumen fractions were characterized qualitatively by GC-MS and quantitatively by GC-FID. $n$-Alkanes, $n$-alkenes, fatty acids and isoprenoids were identified in the extracts. The main components were nalkanes and $n$-alkenes, constituting over $80 \%$ of the total bitumen determined. An unexpected presence of $n$-alkenes only in the free bitumen fraction was found. The possible source of ill-smelling substances evolved during treatment of phosphorite with $\mathrm{H}_{2} \mathrm{SO}_{4}$ was discussed.
\end{abstract}

Keywords: phosphorites, bitumen, composition, odours.

\section{INTRODUCTION}

Phosphorites are a natural source of phosphorus for the phosphoric acid and fertilizer production. They are mainly composed of carbonated hydroxyapatites, chloroapatites and fluoroapatites. The general formula of phosphorites is $\mathrm{Ca}_{5}(\mathrm{~F}, \mathrm{Cl}, \mathrm{OH})\left(\mathrm{PO}_{4}, \mathrm{CO}_{3}\right)_{3}{ }^{1}$. Also, small amounts of organic matter, ranging from 0.3 to 1.7 wt $\%$, occur in the phosphorite sediments. The organic matter includes bitumen (lipids, material soluble in organic solvents), kerogen (the insoluble residue after the bitumen extraction) and humic acids (alkali-soluble, acid-insoluble fraction) ${ }^{2}$. Humic acids normally account for $40-80 \%$ of the total organic matter ${ }^{3}$.

The presence of organic matter $(\mathrm{OM})$ is a consequence of the contribution of living organism in the formation of phosphorites. Studies on the characterization of organic matter of phosphorite deserve major attention from various standpoints, including the genesis and processing of phosphorite and air pollution which follows the phosphoric acid and fertilizer production. OM generates a lot of problems in the phosphorite processing ${ }^{2}$. For the degradation of phosphorite, sulfuric acid is commonly used. Undesirable foaming and difficulties in the filtration of by-product calcium sulfate take place during the wet-process phosphoric acid manufacture. Moreover, the phosphoric acid solution is characterized by undesirable gray-brown colour if the OM content is reasonable. To minimize the effect of $\mathrm{OM}$, the phosphate rock is thermally treated in air at temperatures of around $800^{\circ} \mathrm{C}^{2,4}$.

OM also accounts for the odour nuisances which follows the phosphorite processing. The treatment of phosphorite with sulfuric acid in the industrial production of fertilizers leads to the evolution of volatile organic compounds, including sulfur-containing compounds, making this industry noxious for the environment. It has been reported ${ }^{5}$ that ill-smelling substances are mainly formed in the reaction of $\mathrm{OM}$ with elemental sulfur released during the phosphorite decomposition using $\mathrm{H}_{2} \mathrm{SO}_{4}$. Elemental sulfur, thiophenes and disulfides were found in the phosphogypsum, which is a waste product of the phosphoric acid production. Sulfides, polysulfides and thiophenes were detected in stack gases. The liberation of the organic sulfur compounds, which occur in the raw material, during acid treatment should be also considered $^{2}$. The knowledge about the composition of OM may result in the elaboration of new processing strategies of avoiding odour nuisance for the environment due to conversion of phosphorites into fertilizers.

Most studies on the OM in phosphate rocks have been focused on the understanding the rocks diagenesis and the mechanism of organic matter trapping ${ }^{3,6-8}$. Humic acids are of particular concern due to the highest contribution to the phosphorite organic matter. However, there is a relatively small number of reports on the characterization of bitumen ${ }^{3,9}$ which can contribute to the reactions leading to the formation of ill-smelling substances during phosphorite processing. Bitumen was extracted from Youssoufia phosphate rock (Morocco) using a methanol/benzene mixture and chloroform and subsequently analyzed by GC-MS ${ }^{9}$. It was found that nalkanes ranging from $\mathrm{C}_{15}$ to $\mathrm{C}_{34}$ were the most abundant in the solvent extract. Aliphatic mono- and dicarboxylic acids, with a prevalence of the formers, contributed to a much smaller extent. Isoprenoids, steranes and hopanes were also detected. The distribution of hydrocarbons extracted with chloroform from both the whole phosphorite rock and the humic acids fraction was found to be similar ${ }^{3}$. Generally, the knowledge of the composition of bitumen and the content of particular components is still relatively skimpy.

The overall objective of the work was to characterize the organic matter in terms of its potential contribution in the volatile organic compounds emission during phosphorite processing. Three phosphorite samples were provided by Polish companies producing fertilizers. This study was focused on the organic solvent extractable matter (bitumen) which was qualitatively and quantitatively determined by GC-MS and GC-FID techniques. One of the interests of the study on bitumen of phosphorites is that it can be considered as a precursor of odours emitted during phosphoric acid and fertilizers produc- 
tion $^{10}$. To our best knowledge, the present work is the first which characterizes separately the free and bound bitumens extracted from commercial phosphorites of different deposits.

\section{EXPERIMENTAL}

\section{Samples}

Phosphorites from different basins, i.e. Khouriba (Morocco), Lave Mdilla (Tunisia) and Safaga (Egypt) were the subject of this investigation. The samples were ground in a porcelain mortar to pass the sieve of aperture size $200 \mu \mathrm{m}$ and subsequently dried at $80^{\circ} \mathrm{C}$ for $2 \mathrm{~h}$. The total organic carbon (TOC) was determined according to PN-EN 13137.

\section{Solvent extraction}

The extraction was carried out in two 24-h steps using Soxhlet apparatus. First, the mixture of benzene and methanol $(2: 1, \mathrm{v} / \mathrm{v})$ was applied for the separation of free bitumen. After acidification to $\mathrm{pH} 2$ with a $5 \% \mathrm{HCl}$, the extraction solid residue was subjected to the extraction with chloroform in order to isolate bound bitumen. Each extract was concentrated in a rotary evaporator to about $2 \mathrm{~cm}^{3}$ and subsequently, dried on free air and weighted. Extraction was carried out in duplicate. For the chromatographic analysis the extract was dissolved in $2 \mathrm{~cm}^{3}$ of dichloromethane.

\section{Chromatographic analysis}

The qualitative analysis of the bitumen extract was performed using a Hewlett-Packard 6890 gas chromatograph coupled with a HP5973 mass selective detector (GC-MS). A HP-5MS capillary column (30 m x 0.20 $\mathrm{mm}$ i.d., $0.25 \mu \mathrm{m}$ film thickness, cross-linked $5 \% \mathrm{PH}$ ME siloxane) was used with $\mathrm{He}$ as the carrier gas at a constant rate of $0.7 \mathrm{ml} / \mathrm{min}$. The temperature of the column was programmed from 60 to $280^{\circ} \mathrm{C}$ at $10^{\circ} \mathrm{C} / \mathrm{min}$, after an initial $1 \mathrm{~min}$ isothermal period and kept at the final temperature for $10 \mathrm{~min}$. The inlet was maintained at $260^{\circ} \mathrm{C} .1 \mu \mathrm{l}$ of extract was injected in the split mode (1:10) using a syringe. The mass spectrometer was set at an ionizing voltage of $70 \mathrm{eV}$ with mass range $\mathrm{m} / \mathrm{z}$ 42-600. The identification of bitumen's components was accomplished by comparing retention times (RT) and mass spectra of the resolved organic compounds using computerized library search routine. Mass Spectra Library Version 1.1a was used.

The quantitative analysis was performed using a Hewlett-Packard 5890 gas chromatograph equipped with a FID detector (GC-FID) and a fused capillary column HP-5 $(25 \mathrm{~m} \times 0.25 \mathrm{~mm}$ i.d., $0.25 \mu \mathrm{m}$ film thickness, cross-linked 5\% PH ME siloxane). The temperature program of the oven was the same as for the GC-MS identification. Nitrogen was used as the carrier gas with a constant pressure of 20 psi. For the quantitative analysis, n-decane was used as the internal standard for the determination of n-alkanes, n-alkenes and isoprenoids. For fatty acid methyl esters determination, methyl heptadecanoate (Fluka) was used as the internal standard. For each extract, two GC-FID analyses were performed just after the extraction process. Relative deviation of duplicate determinations was $<5 \%$.

\section{RESULTS AND DISCUSSION}

\section{Extraction yield}

The percentage of the total organic content (TOC) in the phosphorite samples ranges between 0.28 and $0.92 \mathrm{wt} \%$. Table 1 shows the extraction yields of phosphorites with organic solvents. The benzene-methanol extract represents the free bitumen fraction. To release the bitumen bound to the organo-mineral matrix of phosphorite, the residual phosphorite matrix was dissolved with $\mathrm{HCl}$. The bound bitumen was subsequently extracted using chloroform.

Table 1. Characteristics of the extraction process of phosphorites

\begin{tabular}{|l|c|c|c|c|}
\hline Sample & \multirow{2}{*}{$\begin{array}{l}\text { TOC, } \\
\text { wt \% }\end{array}$} & \multicolumn{3}{|c|}{ Extraction yield, wt \% } \\
\cline { 3 - 5 } & & $\begin{array}{c}\text { Benzene- } \\
\text { methanol }\end{array}$ & Chloroform & Total \\
\hline Morocco & 0.28 & 0.20 & 0.04 & 0.24 \\
Tunisia & 0.92 & 0.37 & 0.30 & 0.67 \\
Egypt & 0.33 & 0.41 & 0.80 & 1.21 \\
\hline
\end{tabular}

Based on phosphorites studied, it can be observed that Moroccan phosphorite is characterized by the lowest amount of bitumen with a predominant contribution of free bitumen against the bound one ( 0.20 vs. $0.04 \mathrm{wt} \%)$. A reverse relation is observed in the case of Egyptian phosphorite for which the bound bitumen dominates $(0.41$ vs. $0.80 \mathrm{wt} \%$ ). Tunisian phosphorite shows a slightly higher proportion of free bitumen compared to bound bitumen (0.37 vs. $0.30 \mathrm{wt} \%)$. The obtained results show that an increase of TOC of phosphorite is not followed by the total extraction yield. A reasonable correlation between the TOC and the chloroform extract was reported in the case of phosphatized and non-phosphatized sediments from Gafsa Basin (Tunisia). The highest total yield of extraction was found for Egyptian phosphorite, although its TOC is not the highest among the phosphorites studied. This could suggest that Egyptian phosphoritederived bitumen is characterized by an enhanced amount of heteroatoms.

\section{Qualitative and quantitative analysis of bitumen by GC-MS and GC-FID}

Table 2 presents the content of bitumen determined by GC-FID, expressed in $\mathrm{mg} / \mathrm{kg}$ of dried phosphorite. For Tunisian and Egyptian phosphorites the content of determinable bitumen is similar, amounting to about $65 \mathrm{mg} / \mathrm{kg}$, although the extraction yield for the former phosphorite is much lower than that of the latter one (0.67 vs. 1.21 wt $\%)$. This indicates that Egyptian phosphorite contains a considerable amount of high-molecular weight fraction of bitumen, including N, S, O-containing components of asphaltene-type ${ }^{3}$, which are not detectable by gas chromatography. Both the twice higher yield of extraction with

Table 2. Content of bitumen in phosphorites determined by GC-FID

\begin{tabular}{|l|c|c|c|}
\hline \multirow{2}{*}{ Sample } & \multicolumn{3}{|c|}{ Bitumen, $\mathrm{mg} / \mathrm{kg}$} \\
\cline { 2 - 4 } & Free & Bound & Total \\
\hline Morocco & 19.20 & 8.45 & 27.65 \\
Tunisia & 50.33 & 13.75 & 64.08 \\
Egypt & 53.10 & 11.88 & 64.98 \\
\hline
\end{tabular}


chloroform compared to the benzene-methanol mixture and the small amount of determinable bound bitumen could suggest an enrichment of Egyptian phosphorite in heavier bitumen. Moroccan phosphorite shows the lowest content of determinable bitumen, $27.65 \mathrm{mg} / \mathrm{kg}$. It was found that the bound bitumen represents $18-30 \%$ of the total amount of determinable bitumen in phosphorites, increasing in the direction: Egypt $<$ Tunisia $<$ Morocco.

The GC-MS analysis has revealed the presence of $n$-alkanes, $n$-alkenes, saturated and unsaturated monocarboxylic fatty acids and isoprenoids in the bitumen. Nearly 40 compounds in the free bitumen fraction and almost 20 compounds in the bound bitumen fraction were identified. It should be noticed that this finding concerns only a determinable part of bitumen. Bitumen of high molecular weight, due to its non-volatility, cannot be determined by the GC technique. No sulfur-containing organic compounds were detected in the solvent extract. This could suggest that the sulfur functionalities occurs in the bitumen of high molecular weight. Table 3 contains the results of the GC-FID analysis of free and bound bitumen fractions. The differences in the composition of free and bound bitumen for different phosphorites can be clearly seen. Moroccan- and Egyptian phosphoritederived free bitumen contains a higher amount of $n$ alkanes compared to respective bound bitumen (14.30 vs. $7.85 \mathrm{mg} / \mathrm{kg}$ for Moroccan phosphorite and 16.81 vs. $10.84 \mathrm{mg} / \mathrm{kg}$ for Egyptian phosphorite). A reverse trend can be observed for Tunisian phosphorite, for which bound bitumen is slightly more abundant in $n$-alkanes $(12.02$ vs. $12.79 \mathrm{mg} / \mathrm{kg}$ ). This study shows that while TOC increases, the amount of $n$-alkanes in bound bitumen also increases. It should be emphasized that alkenes and fatty acids were observed in the free bitumen fraction only.

$n$-FAs were detected in the form of methyl esters as a result of transesterification of lipids with methanol during extraction of phosphorite with a benzene-methanol mixture. In our work, we used chloroform for the separation of bound bitumen. Therefore, $n$-FAs could not have been detected due to their low volatility even they were present. Indeed, they were detected in the bound bitumen fraction which was separated with a dichloromethane-methanol mixture ${ }^{\mathbf{1 1}}$.

The contribution of different functionalities in the bitumen extracted from different phosphorites is given in Table 4. As expected, aliphatic hydrocarbons are

Table 3. GC-FID analysis of free and bound bitumens of phosphorites, $\mathrm{mg} / \mathrm{kg}$

\begin{tabular}{|c|c|c|c|c|c|c|c|c|c|c|}
\hline \multirow{2}{*}{ RT } & \multirow{2}{*}{ Compound } & \multicolumn{3}{|c|}{ Morocco } & \multicolumn{3}{|c|}{ Tunisia } & \multicolumn{3}{|c|}{ Egypt } \\
\hline & & Free & Bound & Total & Free & Bound & Total & Free & Bound & Total \\
\hline 10.46 & 1-tetradecene & & & & 6.90 & & 6.90 & 2.92 & & 2.92 \\
\hline 10.56 & tetradecane & 1.63 & & 1.63 & 2.45 & & 2.45 & 0.40 & & 0.40 \\
\hline 10.73 & 5-tetradecene & 0.18 & & 0.18 & 0.54 & & 0.54 & 0.58 & & 0.58 \\
\hline 10.88 & 7-tetradecene & & & & 0.86 & & 0.86 & 0.30 & & 0.30 \\
\hline 11.70 & pentadecane & 1.38 & 0.28 & 1.66 & 0.34 & 0.24 & 0.58 & 0.52 & 0.56 & 1.08 \\
\hline 12.68 & 1-hexadecene & 0.11 & & 0.11 & 6.96 & & 6.96 & 10.18 & & 10.18 \\
\hline 12.99 & hexadecane & 0.82 & 0.50 & 1.32 & 0.79 & 0.50 & 1.29 & 0.40 & 0.48 & 0.88 \\
\hline 13.42 & 5-hexadecene & & & & 0.39 & & 0.39 & 0.68 & & 0.68 \\
\hline 13.61 & 7-hexadecene & 0.11 & & 0.11 & 0.52 & & 0.52 & & & \\
\hline 14.05 & heptadecane & 0.52 & 0.33 & 0.85 & 0.62 & 0.40 & 1.02 & 0.91 & 0.29 & 1.20 \\
\hline 14.09 & pristane & 0.56 & 0.18 & 0.74 & 0.56 & 0.30 & 0.86 & 0.43 & 0.20 & 0.63 \\
\hline 14.92 & 1-octadecene & & & & 6.44 & & 6.44 & 7.43 & & 7.43 \\
\hline 15.14 & octadecane & 0.70 & 0.57 & 1.27 & 0.55 & 0.64 & 1.19 & 1.15 & 1.66 & 2.81 \\
\hline 15.32 & phytane & 0.44 & 0.29 & 0.73 & 0.43 & 0.23 & 0.65 & 0.55 & 0.36 & 0.91 \\
\hline 15.53 & 9-octadecene & & & & 0.24 & & 0.24 & 0.50 & & 0.50 \\
\hline 16.12 & nonadecane & 0.65 & 0.65 & 1.30 & 0.78 & 0.79 & 1.57 & 0.98 & 1.11 & 2.09 \\
\hline 16.37 & methyl (Z)-9-hexadecenoate & 1.96 & & 1.96 & 2.92 & & 2.92 & 4.77 & & 4.77 \\
\hline 16.54 & methyl hexadecanoate & 0.41 & & 0.41 & 2.88 & & 2.88 & 0.33 & & 0.33 \\
\hline 17.04 & 1-eicosene & & & & 3.65 & & 3.65 & 6.70 & & 6.70 \\
\hline 17.12 & eicosane & 1.09 & 0.54 & 1.63 & 0.59 & 1.57 & 2.16 & 0.35 & 0.52 & 0.87 \\
\hline 17.80 & 1-heneicosene & 0.14 & & 0.14 & & & & & & \\
\hline 17.95 & heneicosane & 0.37 & 0.53 & 0.90 & & 0.70 & 0.70 & 0.71 & 0.21 & 0.92 \\
\hline 18.35 & methyl (Z)-9-octadecenoate & 0.18 & & 0.18 & 0.39 & & 0.39 & 0.17 & & 0.17 \\
\hline 18.48 & methyl (E)9-octadecenoate & 0.15 & & 0.15 & & & & & & \\
\hline 18.69 & methyl octadecanoate & 0.17 & & 0.17 & 3.21 & & 3.21 & 0.31 & & 0.31 \\
\hline 18.82 & docosane & 0.94 & 0.65 & 1.59 & 0.25 & 0.87 & 1.12 & 2.44 & 0.85 & 3.29 \\
\hline 19.02 & 11-docosene & 0.11 & & 0.11 & & & & & & \\
\hline 19.59 & tricosane & 0.60 & 0.74 & 1.34 & 0.16 & 0.92 & 1.08 & 0.46 & 0.36 & 0.82 \\
\hline 20.36 & tetracosane & 0.72 & 0.83 & 1.55 & 1.33 & 1.07 & 2.40 & 1.76 & 0.47 & 2.23 \\
\hline 21.10 & pentacosane & 0.79 & 0.77 & 1.56 & 0.43 & 1.21 & 1.64 & 0.73 & 1.42 & 2.15 \\
\hline 21.79 & hexacosane & 0.59 & 0.55 & 1.14 & 0.82 & 0.92 & 1.74 & 1.38 & 1.28 & 2.66 \\
\hline 22.47 & heptacosane & 0.57 & 0.36 & 0.93 & 0.37 & 0.76 & 1.13 & 0.45 & 0.25 & 0.70 \\
\hline 23.11 & octacosane & 0.49 & 0.23 & 0.72 & 1.01 & 0.35 & 1.36 & 0.86 & 0.24 & 1.10 \\
\hline 23.78 & squalene & 0.38 & 0.13 & 0.51 & 1.42 & 0.43 & 1.85 & 0.44 & 0.48 & 0.92 \\
\hline 23.93 & nonacosane & 0.24 & 0.22 & 0.46 & 0.61 & 1.15 & 1.76 & 1.41 & 0.94 & 2.35 \\
\hline 24.52 & triacontane & 0.30 & 0.10 & 0.40 & 0.52 & 0.70 & 1.22 & 0.49 & 0.20 & 0.69 \\
\hline 25.20 & heneitriacontane & 1.57 & & 1.57 & 0.40 & & 0.40 & 1.01 & & 1.01 \\
\hline 26.08 & dotriacontane & & & & & & & 0.40 & & 0.40 \\
\hline \multirow[t]{2}{*}{26.88} & tritriacontane & 0.33 & & 0.33 & & & & & & \\
\hline & Total content: & 19.20 & 8.45 & 27.65 & 50.33 & 13.75 & 64.08 & 53.10 & 11.88 & 64.98 \\
\hline
\end{tabular}


Table 4. Distribution of organic compounds groups in the total bitumen of different phosphorites, \% of total determined OM

\begin{tabular}{|l|c|c|c|c|c|}
\hline Sample & $n$-Alkanes & $n$-Alkenes & $n$-FAs & Isoprenoids & Pristane/phytane ratio \\
\hline Morocco & 80.1 & 2.3 & 10.4 & 7.2 & 1.01 \\
Tunisia & 38.7 & 41.4 & 14.7 & 5.2 & 1.32 \\
Egipt & 42.5 & 45.1 & 8.6 & 3.8 & 0.69 \\
\hline
\end{tabular}

the most abundant in bitumen, constituting more than $80 \%$ of the total amount of the determined OM. The presence of n-alkenes in a reasonable amount in commercial phosphorite samples requires a careful explanation because they have not been detected so far in the phosphorite samples which were collected directly from deposit ${ }^{3,9} . n$-FAs constitute $8.6-14.7 \%$ of the total determined OM. The contribution of isoprenoids is in the range of $3.8-7.2 \%$.

\section{Characterization of solvent-soluble organic matter}

\section{$n$-Alkanes}

Figure 1 shows the gas chromatogram $(m / z 57)$ for saturated hydrocarbons of free (a) and bound (b) bitumen, extracted from Moroccan phosphorite as an example. $n$-Alkanes with carbon number in the range $n-\mathrm{C}_{14}-n-\mathrm{C}_{33}$ were detected in both fractions of bitumen. However, the free bitumen is more abundant in n-alkanes with a lower carbon number compared to the bound bitumen. This finding can be observed for all the phosphorites studied.

The composition of $n$-alkanes in the phosphorites is shown in Figure 2. Moroccan phosphorite is characterized by the most uniform distribution of n-alkanes, ranging from $\mathrm{C}_{14}$ to $\mathrm{C}_{31}$ (Figure 2a). Tunisian phosphorite shows a more differentiated distribution of $n$-alkanes, with a predominance of $\mathrm{C}_{14}, \mathrm{C}_{20}$ and $\mathrm{C}_{24}$ (Figure 2b). For
Egyptian phosphorite, the $n$-alkane profile is dominated by higher carbon number hydrocarbons, i.e., $\mathrm{C}_{18}, \mathrm{C}_{22}$ and $\mathrm{C}_{26}$ (Figure $2 \mathrm{c}$ ).

$n$-Alkanes with a lower carbon number, i.e. $\mathrm{C}_{2}$ to $\mathrm{C}_{9}$ were not detected in our study. They, however, were revealed in the outlet gases evolved during production of single superphosphate from Moroccan phosphorite using thermal desorption in combination with GC-MS ${ }^{\mathbf{1 0}}$. This suggests that the treatment of phosphorite with $\mathrm{H}_{2} \mathrm{SO}_{4}$ can lead to the degradation of long-chain $n$-alkanes of bitumen. Moreover, C1-C3 alkyl cyclopentanes and cyclohexanes, and sulfur-containing compounds, such as C1-C3 alkyl sulfides, C1-C3 alkyl disulfides, and monoand dimethyltetrahydrothiophenes were detected in the post-reaction gases ${ }^{3}$. The presence of organic sulfur functionalities can be explained by the decomposition of sulfur-containing high molecular weight bitumen and secondary reactions of aliphatic hydrocarbons with elemental sulfur ${ }^{\mathbf{1 2 , 1 3}}$ released during phosphorite treatment with $\mathrm{H}_{2} \mathrm{SO}_{4}$.

\section{$n$-Alkenes}

Even numbered n-alkenes in the range from $\mathrm{C}_{14: 1}$ to $\mathrm{C}_{20: 1}$ were detected in reasonable amounts in the free bitumen extracted from Tunisian and Egyptian phosphorites, 26.50 and $29.29 \mathrm{mg} / \mathrm{kg}$, respectively (Table 3). The
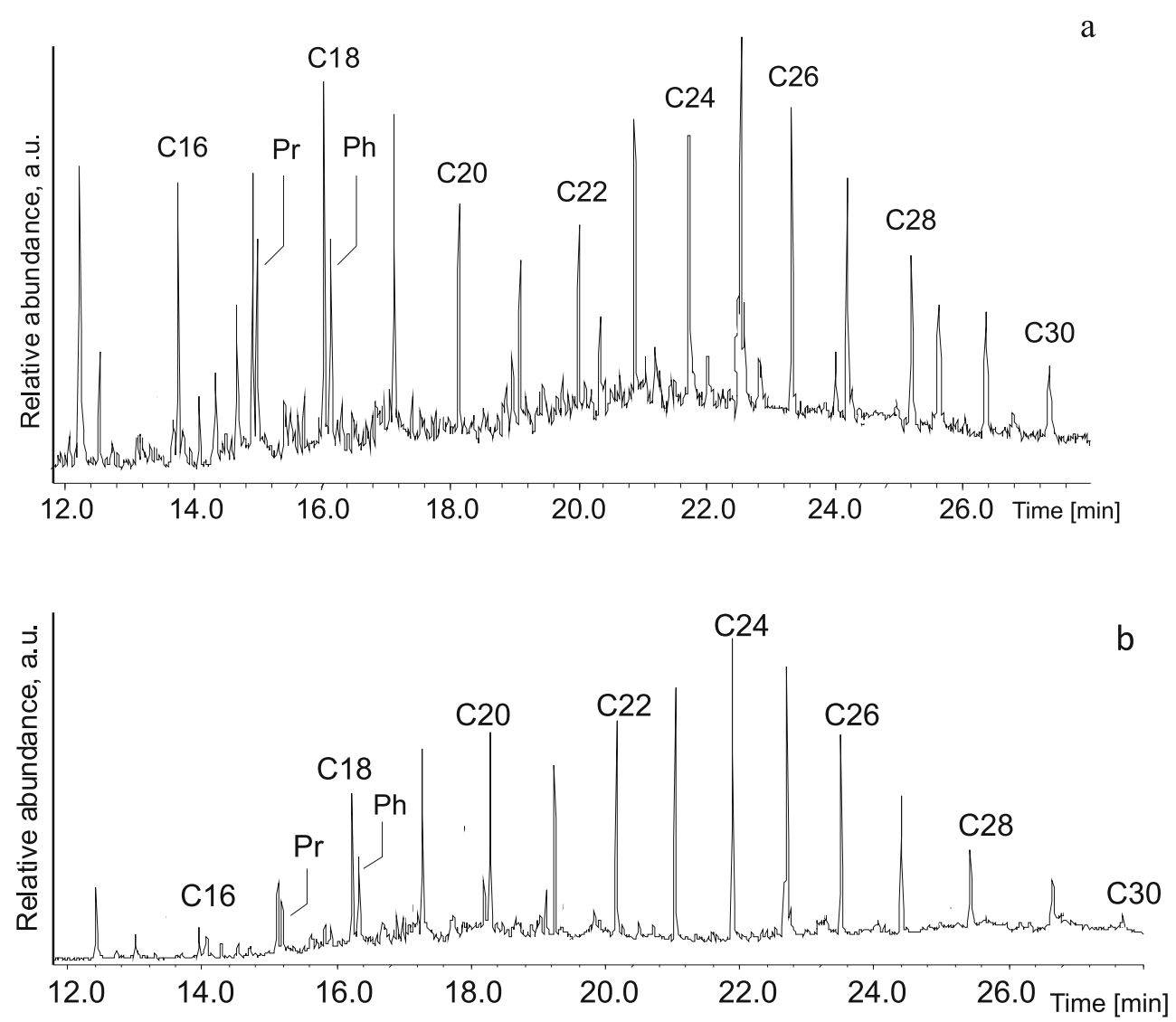

Figure 1. Partial ion chromatogram $m / z 57$ of a, benzene-methanol extract and b, chloroform extract obtained from Moroccan phosphorite. Pr, pristane; $\mathrm{Ph}$, phytane 


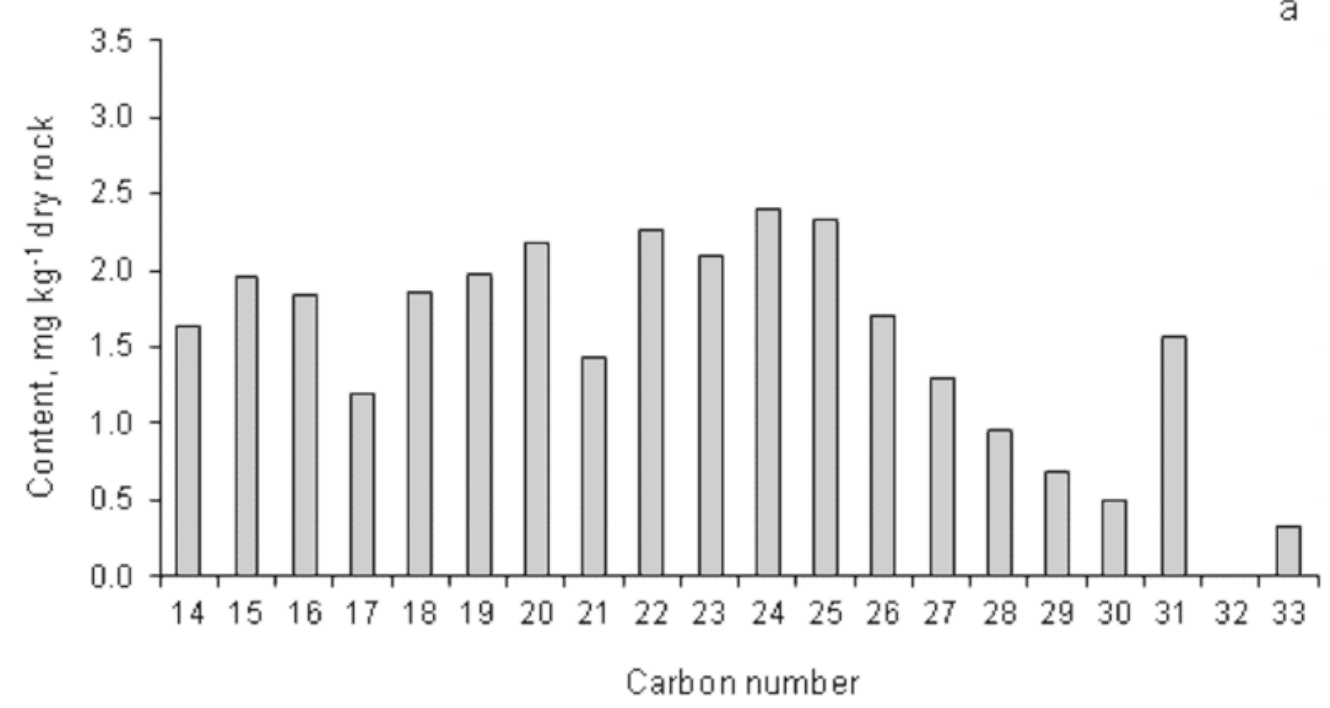

b
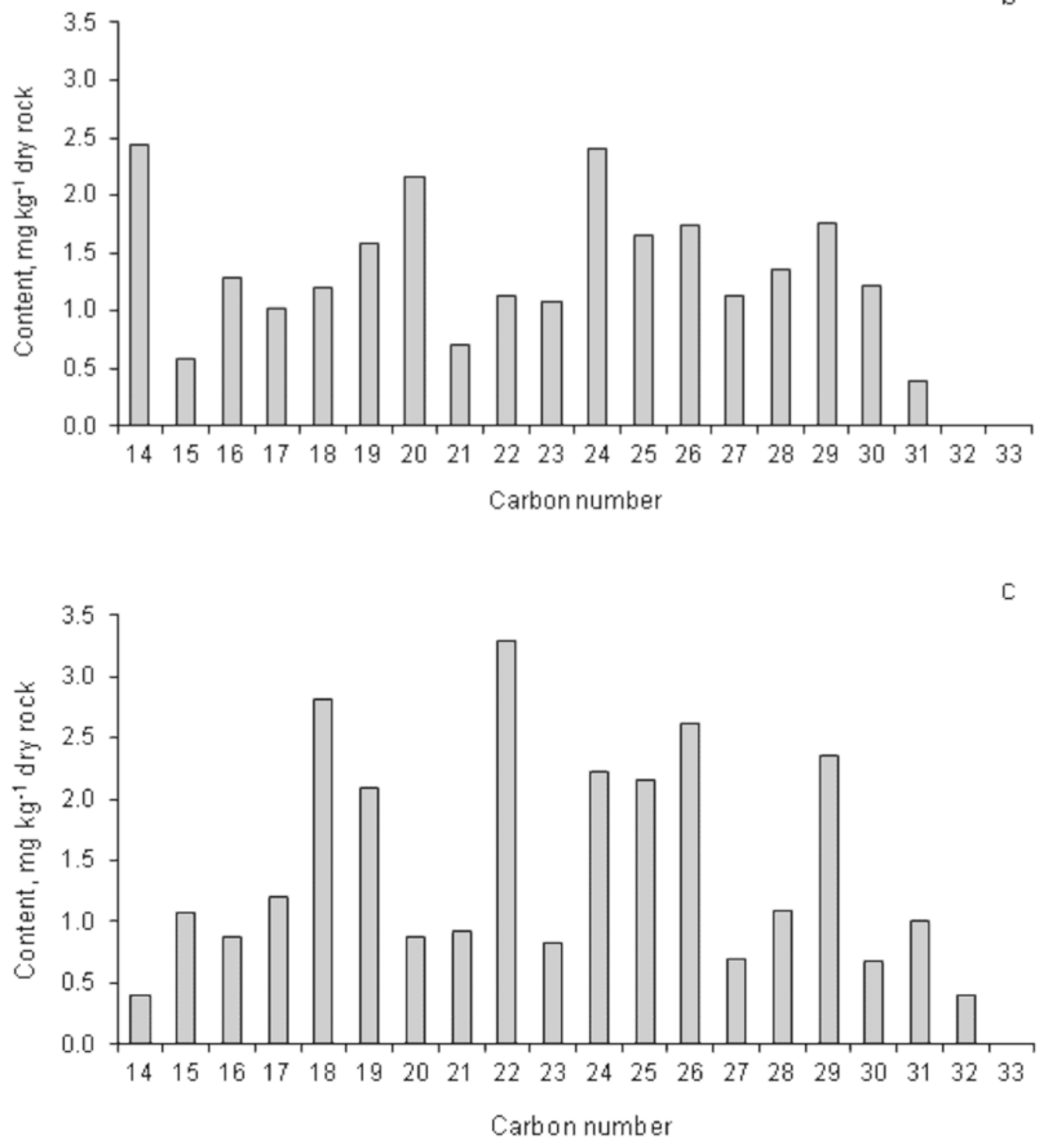

Figure 2. $n$-Alkane distribution in a, Moroccan phosphorite; b, Tunisian phosphorite; c, Egyptian phosphorite (expressed as mean values)

distribution of n-alkenes in the free bitumen fraction of phosphorites is shown in Figure 3. It is interesting to note, that among $n$-alkenes the predominance of $n$-alk1-enes can be observed. This could be an indicator of recent biogenesis ${ }^{1}$. It was reported that even numbered $n$-alk-1-enes may have originated from unsaturated fatty acids $^{14}$. Other researchers consider the possibility of $n$-alkenes formation from $n$-alkanes during a long process of extraction with a benzene-ethanol mixture in Soxhlet apparatus $^{15}$. To explain the reason for the presence of 


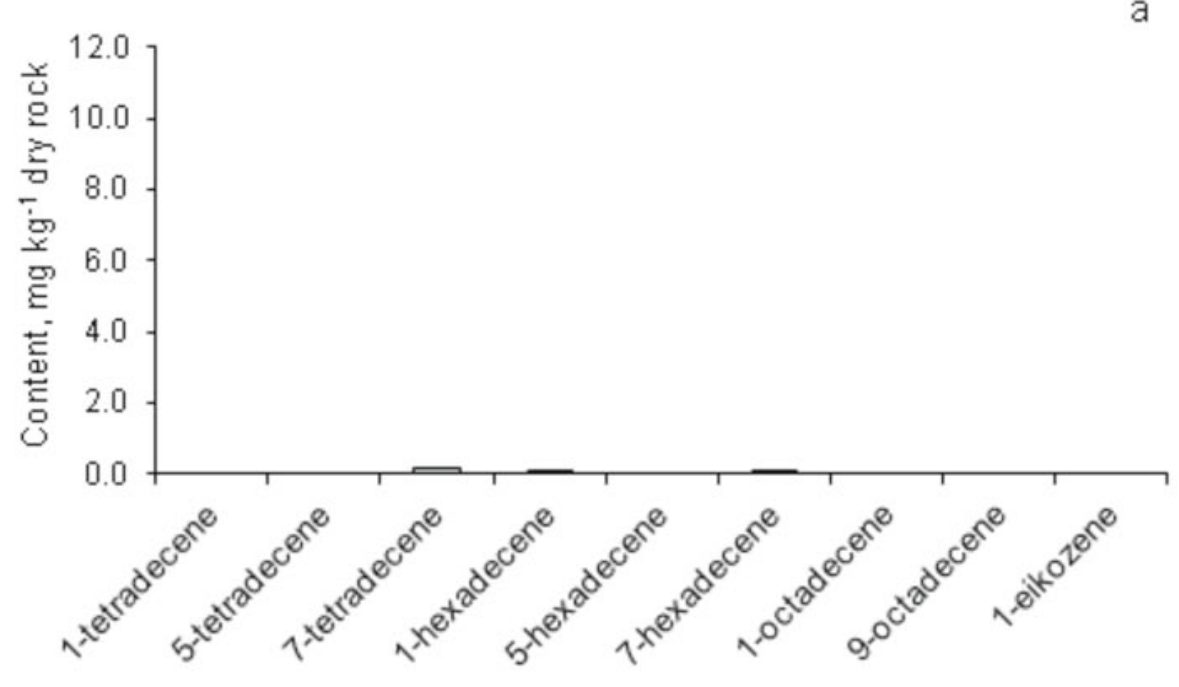

b
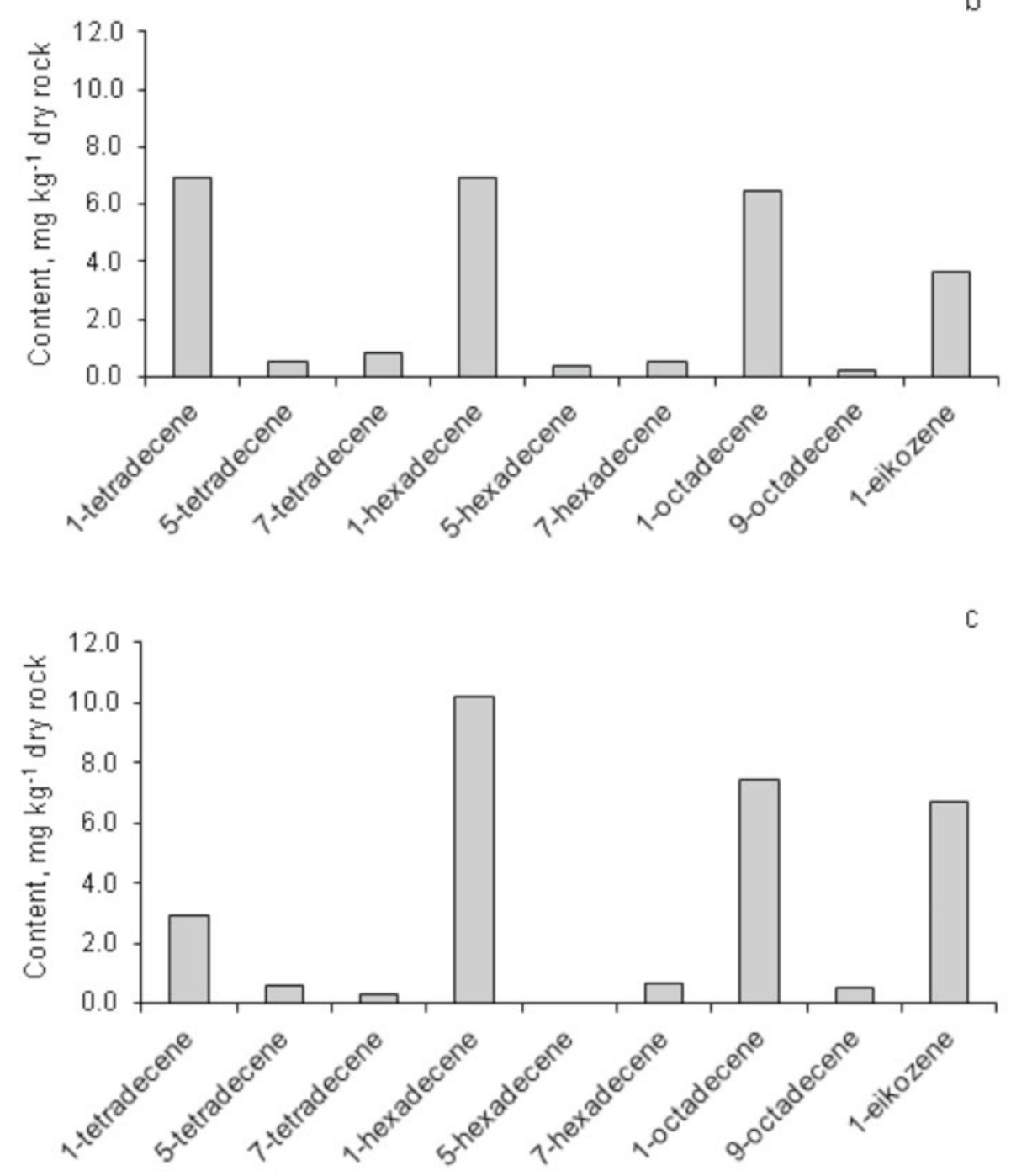

Figure 3. $n$-Alkene distribution in a, Moroccan phosphorite; b, Tunisian phosphorite; c, Egyptian phosphorite (expressed as mean values)

alkenes in the free bitumen fraction, further study is required. Alkenes can easily react with elemental sulfur giving organic sulfur compounds ${ }^{12,13}$.
$n$-FA

Figure 4 shows the distribution of saturated and unsaturated fatty acids in the free bitumen of phosphorites. Tunisian phosphorite is characterized by the highest amount of $n$-FAs acids, $9.40 \mathrm{mg} / \mathrm{kg}$. Monocarboxylic acids, palmitic $\left(\mathrm{C}_{16}\right)$ and stearic $\left(\mathrm{C}_{18}\right)$, were identified in all the 

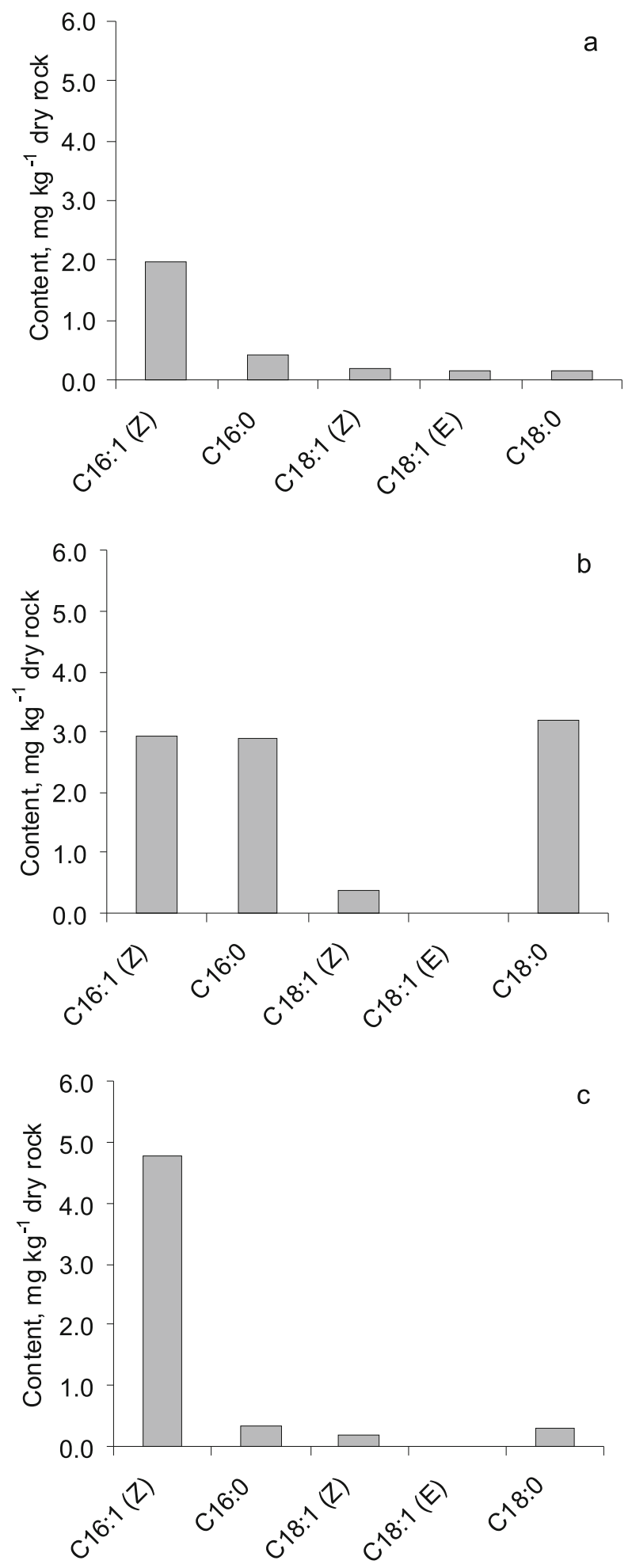

Figure 4. Fatty acids distribution in a, Moroccan phosphorite; b, Tunisian phosphorite; c, Egyptian phosphorite (expressed as mean values)

phosphorites. These $n$-FAs are characteristic for biological genesis, being the major lipid components of organisms. They are geochemically stable and derive from ancient and recent sediments ${ }^{1}$. Unsaturated monocarboxylic acids, $\mathrm{C}_{16: 1}$ and $\mathrm{C}_{18: 1}$, were also detected. n-FAs can be also considered as precursors of odour substances emitted during fertilizer production. The reaction of $n$-FAs with elemental sulfur, which leads to the formation of oligomeric sulfides and thiophenic compounds is known ${ }^{16}$.
Isoprenoids

The three isoprenoids, pristane (2,6,10,14-tetramethylpentadecane), phytane (2,6,10,14-tetramethylhexadecane) and squalene ((E,E,E,E)-2,6,10,15,19,23-hexamethyl-2,6,10,14,18,22-tetracosahexane) were identified by GC-MS in all phosphorite samples. Table 3 shows that the abundance of isoprenoids is the highest for Tunisian phosphorite $(3.36 \mathrm{mg} / \mathrm{kg})$ and the lowest for Moroccan phosphorite $(1.98 \mathrm{mg} / \mathrm{kg})$. The pristane/phytane ratio is used as a paleoenvironmental indicator giving information about the maturity of phosphate $\operatorname{rock}^{17}$.

\section{CONCLUSIONS}

The GC-MS and GC-FID analysis of bitumen, i.e. solvent-soluble organic matter of phosphorite, reveals the presence of aliphatic hydrocarbons and fatty acids which can be considered as precursors of volatile organic compounds evolved during degradation of phosphorite with $\mathrm{H}_{2} \mathrm{SO}_{4}$. Two sequential steps of extraction were applied to maximize the yield of bitumen, using a benzenemethanol mixture and chloroform. The total bitumen content in the studied phosphorite was within the range 0.24-1.21 wt\%. In contrast to Moroccan phosphorite, for Tunisian and Egyptian phosphorites the yield of the benzene-methanol extract was higher than that of the chloroform extract. The amount of the bound bitumen determined by GC represents only $18-30 \%$ of the total determinable bitumen in phosphorites. This suggests that the bitumen bound to the organo-mineral matrix of phosphorite is composed of less volatile and higher molecular weight compounds compared to the free bitumen. n-Alkane, $n$-alkene, isoprenoids, unsaturated and saturated fatty acids were detected in the free bitumen fraction of phosphorite. $n$-Alkanes and isoprenoids only were identified in the bound bitumen fraction separated with chloroform after dissolving inorganic matrix of phosphorite. Aliphatic hydrocarbons in the range of $\mathrm{C}_{14}-\mathrm{C}_{33}$ constituted over $80 \%$ of the total determined OM. The phosphorites were characterized by a different distribution of $n$-alkanes. The Moroccan phosphorite shows the most uniform distribution of $n$-alkanes within range of $\mathrm{C}_{14}-\mathrm{C}_{31}$. For the Tunisian phosphorite $n$-alkanes profile is dominated by $\mathrm{C}_{14}, \mathrm{C}_{20}$ and $\mathrm{C}_{24}$. The predominance of the higher carbon number hydrocarbons, $\mathrm{C}_{18}, \mathrm{C}_{22}$ and $\mathrm{C}_{26}$, is observed in the case of Egyptian phosphorite. The unusual occurrence of even $n$-alkenes in the free bitumen fraction was observed. Their origin is, however, unclear and requires further investigation. Aliphatic hydrocarbons with a low carbon number were preferentially extracted with benzene-methanol mixture.

The lack of sulfur compounds detected by GC/MS in the benzene-methanol and chloroform extracts could suggest that sulfur is bound to high molecular weight fraction of bitumen that cannot be determined by gas chromatography.

\section{ACKNOWLEDGEMENT}

This work was financed by a statutory activity subsidy from the Polish Ministry of Science and Higher Education for the Faculty of Chemistry of Wrocław University of Technology and the project PBZ-MEiN-5/2/2006. 


\section{LITERATURE CITED}

1. Tucker, M.E. (2001). Sedimentary Petrology (3rd ed.), Osney Nead, Blackwell Science.

2. Mair, A.D. (1985) Organic matter and sulfur distribution in phosphorites, National Fertilizer Development Center, USA: Muscle Shoals.

3. Belayouni, H. \& Trichet, J. (1984). Hydrocarbons in phosphatized and non-phosphatized sediments from the phosphate basin of Gafsa, Org. Geochem. 6, 741-754. DOI: 10.1016/01466380(84)90095-0.

4. Blazy, P. \& Bouhaouss, A. (2005). Removal of organic matter in Moroccan Youssoufia phosphate by flash calcinations. Miner. Metall. Process. 2, 107-115.

5. Westerlich, S., Jagodziński, T.S., Paterkowski, W. \& Jagodzińska, E. (2005). Determination of organic compounds from phosphoric acid production by the extraction method, Pol. $J$. Chem. Techn. 4, 55-59.

6. Belayouni, H., Slansky, M. \& Trichet, J. (1990). A study of the organic matter in Tunisian phosphates series: Relevance to phosphorite genesis in the Gafsa Basin (Tunisia), Org. Geochem. 15, 47-72. DOI: 10.1016/0146-6380(90)90184-2.

7. Amit, O. \& Bein, A. 1982. Organic matter in Senonian phosphorites from Israel - Origin and diagenesis, Chem. Geol. 37, 277-287. DOI: 10.1016/0009-2541(82)90083-3.

8. Trichet, J. \& Fikri, J. (1997). Organic matter in the genesis of high-island atoll peloidal phosphorites: the lagoonal link, J. Sed. Res. 67, 891-897. DOI: 10.1306/D426866C-2B26-11D78648000102C1865D.

9. Khaddor, M., Ziyad, M., Halim, M., Joffre, J. \& Amblès, A. (1997). Characterization of soluble organic matter from Youssoufia rock phosphate, Fuel 76, 1395-1400. DOI: 10.1016/ S0016-2361(97)00147-6.

10. Hoffmann, J., Gryglewicz, G., Hoffmann, K., Gryglewicz, S., Okereke, W. \& Skut, J. (2009). Emission of the odour substances from fertilizer industry, Pol. J. Chem. Technol. 11, 12-15. DOI: 10.2478/v10026-009-0004-3.

11. Arning, E.T., Birgel, D., Brunner, B. \& Peckmann, J. (2009). Bacterial formation of phosphatic laminites of Peru, Geobiology 7, 295-307. DOI: 10.1111/j.1472-4669.2009.00197.x.

12. Rasmussen, H.E., Hansford, R.C. \& Sachanen, A.N. (1946). Reaction of aliphatic hydrocarbons with sulfur, Ind. Eng. Chem. 38, 376-382. DOI: 10.1021/ie50436a011.

13. Horton, A.W. (1949). The mechanism of the reaction of hydrocarbons with sulfur, J. Org. Chem. 14, 761-770. DOI: 10.1021/jo01157a007.

14. Del, Rio, J.C. \& Philp, R.P. (1992). Oligomerization of fatty acids as a possible source for high molecular weight hydrocarbons and sulfur-containing compounds in sediments, Org. Geochem. 18, 869-880. DOI: 10.1016/0146-6380(92)90055-3.

15. Okpo, B.O., Oyo-Ita, O.E. \& Wehner, H. (2005). Even-n-alkane/alkene predominances in surface sediments from the Calabar River, SE Niger Delta, Nigeria, Naturwissenschaften 92, 341-346. DOI: 10.1007/s00114-005-0639-8.

16. Chaffee, A.L., Hoover, D.S., Johns, R.B., and Schweighardt, F.K. (1986). Biological markers extractable from coal. In R.B. Johns (Ed), Biological Markers in the Sedimentary Record (pp. 311-346). Elsevier, Amsterdam.

17. Volkman, J.K. \& Maxwell, J.R. (1986). Acyclic isoprenoids as biological markers. In R.B. Johns (Ed.) Biological Markers in the Sedimentary Record (pp. 1-42), Elsevier, Amsterdam. 